\title{
Virtual Methodology for Household Waste Characterization During The Pandemic in An Urban District of Peru: Citizen Science for Waste Management
}

\author{
Norvin Requena-Sanchez ${ }^{1}$ Dalia Carbonel-Ramos $\mathbb{B}^{1} \cdot$ Stephan Moonsammy $^{2} \cdot$ Robert Klaus $^{3} \cdot$ \\ Leoncio Sicha Punil ${ }^{3} \cdot$ Kelvin Tsun Wai $\mathrm{Ng}^{4}$
}

Received: 4 October 2021 / Accepted: 7 February 2022 / Published online: 22 February 2022

(c) The Author(s), under exclusive licence to Springer Science+Business Media, LLC, part of Springer Nature 2022

\begin{abstract}
The Covid-19 pandemic has caused the alteration of many aspects of the solid waste management chain, such as variations in the waste composition, generation and disposal. Various studies have examined these changes with analysis of integrated waste management strategies; qualitative studies on perceived variations and statistical evaluations based on waste collected or disposed in landfills. Despite this information there is a need for updated data on waste generation and composition, especially in developing countries. The objective of this article is to develop a data sampling and analytical approach for the collection of data on household waste generation and composition during the pandemic; and, in addition, estimate the daily generation of masks in the study area. The proposed methodology is based on the principles of citizen science and utilizes virtual tools to contact participants, and for the training and collection of information. The study participants collected the information, installed segregation bins in their homes and trained their relatives in waste segregation. The article presents the results of the application of the methodology in an urban district of Lima (Peru) in August 2020. The results suggest an apparent decrease in household waste per capita and a slight increase in plastics composition in the study area. It is estimated that each participant generates 0.124 masks per day and 0.085 pairs of gloves per day. The method developed and results presented can be used as a tool for public awareness and training on household waste characterization and segregation. Furthermore it can provide the necessary evidence to inform policy directives in response household waste issues and Covid-19 restrictions.
\end{abstract}

Keywords Bio-medical waste management $\cdot$ Disposable masks $\cdot$ Participatory methods $\cdot$ Waste composition $\cdot$ Waste generation

Supplementary information The online version contains supplementary material available at https://doi.org/10.1007/s00267022-01610-1.

Dalia Carbonel-Ramos

dcarbonelr@uni.pe

1 Solid Waste Technical Team, Faculty of Environmental Engineering, National University of Engineering, Tupac Amaru Av 210, 15333 Rímac, Peru

2 Department of Environmental Studies, Faculty of Earth and Environmental Sciences, University of Guyana, Georgetown, Guyana

3 Environmental Management Office, Municipality of Comas, 15328 Comas, Peru

4 Environmental Systems Engineering, Faculty of Engineering and Applied Science, University of Regina, Regina, SK S4S 0A2, Canada

\section{Introduction}

In 2020 the Covid-19 pandemic caused strict quarantines in almost all cities in the world (Jribi et al. 2020). In Peru the first Covid-19 case was reported in March 2020 and days later a lockdown was decreed. In Lima, the strict quarantine lasted until June 2020, from that date the mobility and commerce restrictions were gradually lifted. However, as of mid-June 2021, the city was still partially quarantined, with schools and universities having not resumed face-to-face classes and remote work continuing to be the norm for part of the population (Vega Córdova 2021).

The quarantines and social distancing measures imposed produced a series of positive environmental impacts such as the reduction of air and water pollution (Saadat et al. 2020), decrease in noise pollution, decline on energy consumption 
and greenhouse gas emissions and, lessening on wildlife trade and deforestation (Patrício Silva et al. 2021). However, several negative environmental impacts have also emerged, for example, diminution in indoor air quality (Patrício Silva et al. 2021); higher levels of persistent chemicals in wastewater due to the increased consumption of antibiotics, sanitizers and disinfectants (Elsaid et al. 2021); and an increase of medical waste (Singh and Tirkey 2021), especially masks, gloves and hand sanitizers (Bashir et al. 2020, Thakur 2021).

\section{Analysis of the Covid-19 Impact in Solid Waste Management}

To examine the effects that the Covid-19 pandemic has caused in waste management, various approaches have been used, including the analysis of variations in waste management strategies; statistical studies of fluctuations in the amount of waste generated and; qualitative evaluations of the changes perceived by specialists, local authorities and the general population. Some researchers have carried out studies on the main challenges that the pandemic has posed for waste management. These reports do not focus on specific areas or countries but rather on the common problems faced by the waste management systems on a whole. Nghiem et al. (2020) analysed the implications of the virus survival in different environments, in the generation, segregation, collection, recovery and disposal of waste. Sharma et al. (2020) analysed the strengths and weaknesses of different waste systems focusing on the types of waste of greatest concern during the pandemic such as medical, plastic and food waste.

Quantitative studies have also been carried out based on waste collection and disposal data during the pandemic provided by the government and the private sector. In the case of Shanghai, Brno (Fan et al. 2021) and Sao Paolo (Urban and Nakada 2021) the data released by the government allowed the researchers to make statistical comparisons to identify the variations caused by the pandemic. Other studies used data from weighing at the entrance of sanitary landfills; for example in Regina, Canada (Richter et al. 2021b) and Khenifra, Morocco (Ouhsine et al. 2020). In Regina the researchers observe noticeable differences in waste composition during Covid-19 (Vu et al. 2021). In Khenifra the quantitative data revealed a decrease in waste generation between February and March 2020 (Ouhsine et al. 2020). However, there is a lot of disparity in the amount of data available and in level of analysis made by each of the studies. In Shangai, Brno and Khenifra the analysis only took into account the two previous years (2019 and 2020). In Sao Pao the researches analysed data from the past 10 years, and in Canada from the past 7 years; the former utilized descriptive statistics tools whereas the latter used more sophisticated and visual statistics graphs.
Other studies have made use of qualitative information from online surveys and telephone interviews. Most of these interviews were conducted with local officials and specialists, and surveys were applied to common citizens. The scope of these studies included the variations in waste generation, collection and disposal; the use of waste segregation points during the pandemic; the use and disposal of personal protective equipment (PPE) including masks and gloves and; the variations in the generation of food waste.

\section{Qualitative Analysis of Urban Waste Changes during the Pandemic}

In Iran, a questionnaire was applied to municipal officials and waste management specialists to understand fluctuations in solid waste generation, disposal and collection (Zand and Heir 2021). The information allowed the identification of main changes in the waste collection and disposal systems. Given the availability of data on medical waste, the researchers carried out a more detailed analysis of the variation of this type of waste. They found an increase in medical waste during the pandemic. Regarding the use of gloves and masks, the daily generation of masks was estimated for two scenarios; with and without legislation that requires the use of masks. Researchers estimate that if the use of masks is not mandatory, the level of acceptance will decrease over the months. This research focused on the technician's points of view and understanding the main challenging they faced.

Another study conducted in Guyana and Nigeria (Moonsammy et al. 2021) implemented online surveys to identify the effects of the pandemic on waste generation and collection and how this perpetuates illegal waste disposal. In the case of Guyana, the probability of improper disposal increased along with the alterations in the collection schedule and proximity to a sanitary landfill; in Nigeria, the surge in waste generation augmented the frequency of improper disposal. In both cases, people involved with recycling activities tend to dispose their waste via the formal collection systems. This research reflected the waste disposal practices of common citizens using a considerable sample (216 in Guyana and 273 for Nigeria). The anonymous quality of the survey probably allowed the researchers to gathered more sincere responses and have a more exact assessment of the impacts of quarantine on waste disposal.

In Mexico, Toledo Cervantes et al. (2020) analysed changes in cleaning habits, disinfection and disposal of household waste since the pandemic. The researchers evaluated the use of "clean points" to deposit recyclable waste during quarantine. The ethnographic research described the modifications in the behaviour of people, caused by the pandemic, and made recommendations to the local government to improve the techniques related to waste 
collection and disposal. The latter research was more descriptive and observational in practice; this might result in a biased report influenced by the researcher's point of view. Furthermore there aren't sufficient inputs from interviews or surveys to formulate the conclusions of the study.

In Bangladesh, Islam et al. (2021) and in Poland, Nowakowski et al. (2020), conducted studies to examine the disposal of PPE during the pandemic, specifically masks and gloves. In Bangladesh the research focused on water, sanitation and hygiene practices. As the objective of the researches was to known the disposal practice of common citizens the study completed a total of 1353 participants, all of whom answer the questions virtually. The results indicate that masks and gloves are disposed together with household waste, which poses a risk to waste collection personnel. In Poland, Nowakowski et al. (2020) studied the use and disposal of PPE among local authorities. The researchers reported that a large part of residents disposed their masks and gloves together with common waste or recyclable plastics. The surveyed officials suggested a separate collection stream for this type of waste, either in special containers, through the delivery of special bags or the installation of collection points. Researchers survey a total of 150 individuals using Google Forms.

In Tunisia, Jribi et al. (2020) examined the generation of food waste during the pandemic in middle class households utilizing online surveys. The disturbances in the food supply chains and the strict confinement at the beginning of the pandemic motivated the researchers to assess the perception of the respondents regarding the transformations that the pandemic produced in the generation of food waste and groceries shopping habits. The researchers found that the Covid-19 lockdown pushed participants toward a positive behavioural change, probably driven more by the socioeconomical context of the pandemic than by environmental concerns. In Romania Burlea-Schiopoiu et al. (2021) analysed the impact of the pandemic on food waste among collegue students. In this case, there was also a reduction in the generation of food waste and a greater awareness of the environmental consequences of food waste. Although targeting different types of populations, both studies arrived to similar conclusions; the Covid-19 quarantine had a relatively positive effect on food waste reduction.

\section{Collecting Waste Management Data in Developing Countries}

Waste management data allows governments to select appropriate management methods and design adequate systems for the collection, treatment and disposal of waste (Kaza et al. 2018). In Latin America, for example, only the cities of Quito and Sao Paolo have publicly available monthly data on waste disposal (EMGIRS 2020, São Paolo 2020). In the rest of the cities of the region, these type of data are not collected and/or disseminated (Tello Espinoza et al. 2011). In many African countries, statistics on waste generation, collections treatment and disposal is very limited. Overall, systematic public reporting on waste data is largely limited to highincome countries and some middle-income countries with the World Bank reporting that 231 countries lack data on waste information systems (Kaza et al. 2018). For this reason, it is important to develop tools that allow the collection of quantitative data on waste generation and composition to understand the impacts of the pandemic in developing countries and thus be able to make the necessary corrections and improvements in waste management.

\section{Citizen Science for Collecting Waste Management Data}

A very useful tool for collecting this type of data is citizen science. Citizen science can be defined as the participation of people in scientific activities that may include recording and monitoring of various sorts of data (Pocock et al. 2019). As some authors have previously stated citizen science can be defined using three main components; public participation, voluntary contributions and knowledge production (Adams 2019, Fraisl et al. 2020). Within this framework the public engagement may have different degrees of participation (Fraisl et al. 2020). In our case the involvement of participants fits more closely with the contributory project type, when the project is designed by scientists and volunteers are mostly involved in collecting data.

Citizen science approach has proven to increase engagement and awareness amongst participants (Mitchell et al. 2017). In the environmental field, citizen science has been used in conservation, ecology and environmental pollution issues (Pocock et al. 2019). Citizen science in waste management has largely been utilized from a pollution perspective, mainly in the assessment of plastic contamination in marine ecosystems. For example, evaluating the presence of microplastics on shorelines in the Bahamas (Ambrose et al. 2019), analysing the presence of metals in microplastics collected on shorelines in Australia (Carbery et al. 2020) or studying litter on beaches in China (Chen et al. 2020). Citizen science in the study of solid waste characterization is an issue that has not been explored. As far as the authors are aware, there has only been one study of this type carried out in Argentina (Pierini et al. 2021), where citizens separated and weighed their waste for a week.

The methodology presented in this study proposes a novel way to collect information on household waste characterization in confined conditions using citizen science and without the requirement of house-to-house data collection. This tool can also be used as an awareness technique for waste reduction and segregation. The objective of 
this article is to develop a data sampling and analytical approach for the collection of data on household waste generation and composition during the pandemic. The method would be demonstrated by quantifying household waste generation, waste composition and daily generation of masks in the study area. Unlike other studies that apply surveys and questionnaires to common citizens (Islam et al. 2021, Jribi et al. 2020, Moonsammy et al. 2021, Nowakowski et al. 2020), this study involves them in the generation of information. Furthermore, it teaches them to implement a household waste characterization study within their homes and accompanies them in the process of installing segregation bins in their houses and train their family members.

The main benefit of the proposed methodology is the educational and awareness aspect. Participants receive training in household waste characterization and have the opportunity to practice what they have learned at home and train their families. The methodology can be applied as an environmental education technique since participants are trained to carry out waste segregation activities, install segregation bins in their homes, make compost, elaborate eco-bricks, etc. Other benefits of the proposed methodology are the collection of data on waste characterization for decision-making, lower consumption of resources compare to community fieldwork-based studies and reducing the risk of contracting Covid-19 from collecting household survey data. The application of this proposed methodology is a viable alternative in urban areas with Internet access. Even in situations of strict confinement this proposed methodology can be applied without major inconveniences.

\section{Methodology}

The study was organized and conducted by the Solid Waste Technical Team of the Faculty of Environmental Engineering of the National University of Engineering (ETRS FIA-UNI), in coordination with the Office of Environmental Management of the Municipality of Comas.

\section{Study Area}

The study was carried out in the Comas district, an urban area located in the city of Lima, capital of Peru (Fig. 1). It has a total population of 575,800 (CPI 2019). The Comas district is the fourth most populated district in Lima and in Peru (CPI 2019); furthermore it has one of the highest rates of demographic growth, as in recent years it grew at a rate of 3\% mainly due to national migration (Municipalidad Distrital de Comas 2021). This area is a good representation of the middle class in the Lima Metropolitan area. According to the household income per capita, half of the population is middle class (53.3\%) and majority of the other half is lower middle class (40.8\%) (INEI 2021). The area was selected due to previous contacts with local government officials from the Environment Office and their willingness to contribute to this research.

As stated by the Ministry of Health, as of June 16, 2021, the Comas district has been one of the most affected with the Covid-19 in Metropolitan Lima; during the first six months of 2021, a total of 17,328 cases have been reported, which represents $4.5 \%$ of the Lima region. (Ministerio de Salud 2021).

Fig. 1 Location of the study area

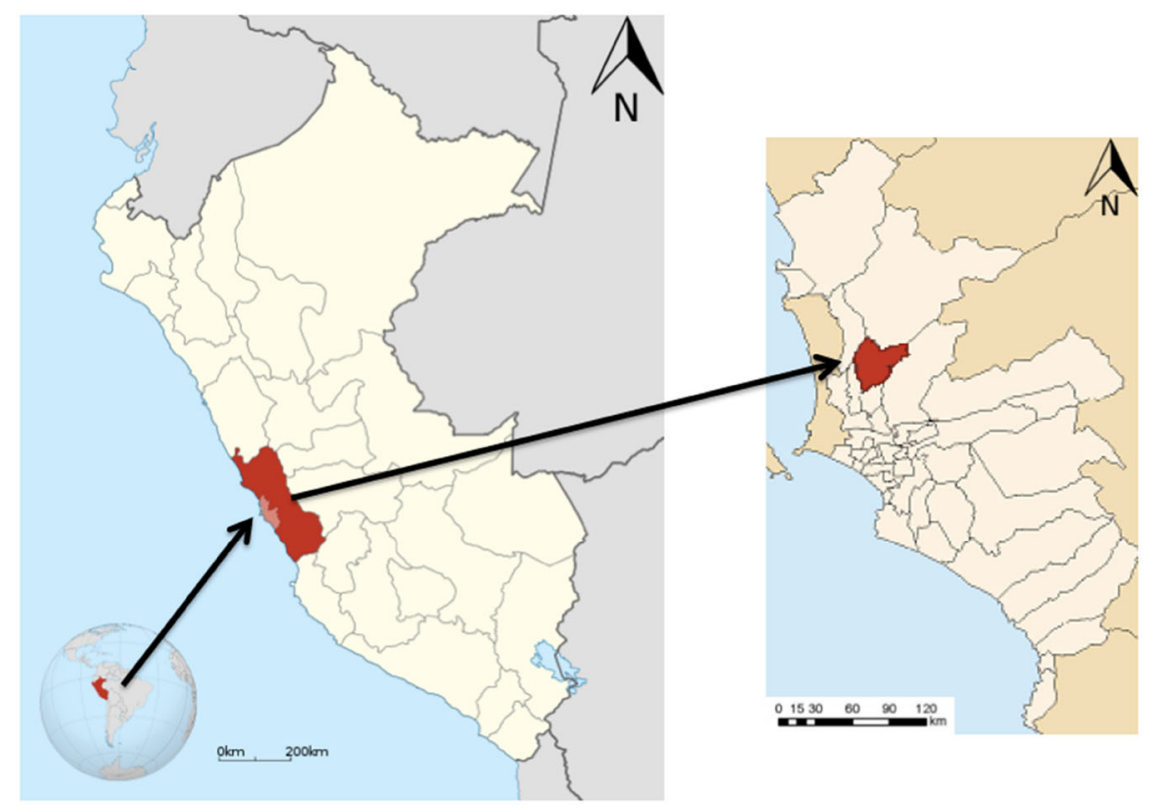


Fig. 2 Segregation bins elaborated by the participants of the study and installed at their home. Photos (a) depicted the four segregation bins installed: organic, hazardous, non recyclable and recyclable waste; photo (b) shows the organics, recyclable, non-recyclable and hazardous waste bins; photo (c) shows, besides the four segregation bins (hazardous, organics, recyclable and nonrecyclable), containers for the ecobrick (left side) and used cooking oil (right side)

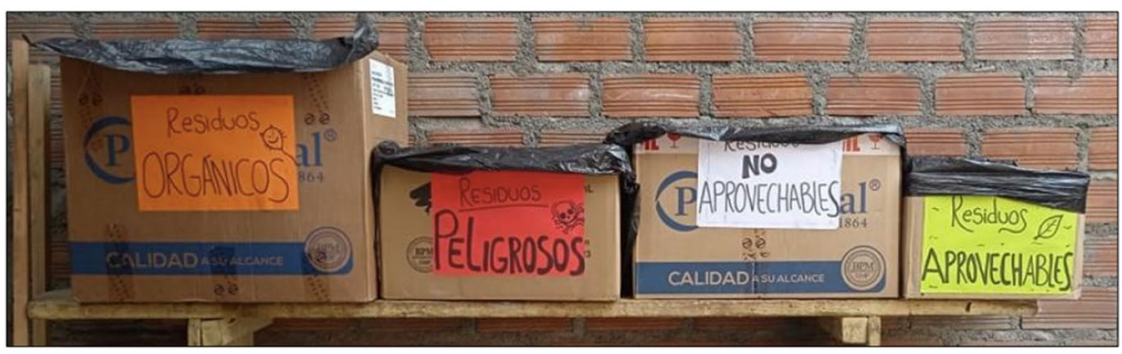

(a)

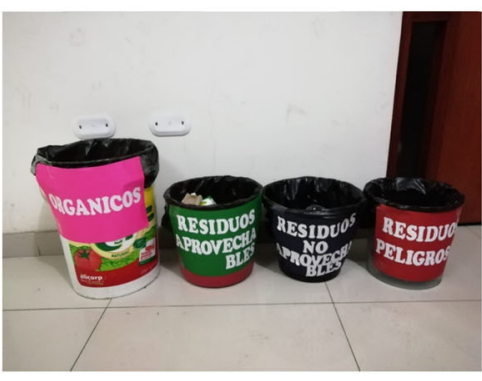

(b)

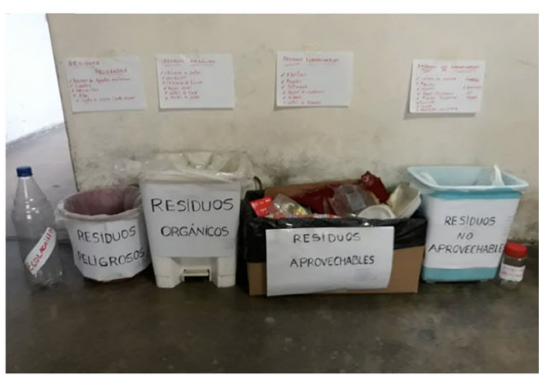

(c)

\section{Waste Characterization Study}

The methodology consists of three phases; (1) call and registration, (2) training and awareness, and (3) data collection and analysis. In total, four virtual sessions were held on: (i) solid waste management, (ii) explanation of the study methodology, (iii) composting and organic gardens at home and, (iv) devolution of preliminary results. The training sessions and data collection instruments (questionnaires, Word templates and Google forms) were conducted in Spanish, English versions are provided in the supplementary section.

In Phase 1, on August 2020, a call (Figure S1) was made through the ETRS FIA-UNI Facebook page. Involvement in the study was voluntary; the participants did not receive any financial incentives. Facebook was chosen because it is the only social network managed by the ETRS FIA-UNI; and also, in Peru, Facebook is the social network with more users (Adco 2020). The study sample consisted of those people who responded to the call made on Facebook. Interested people registered using a Google form (Table $\mathrm{S} 1$ ), in this, they also completed a survey on waste segregation and waste generation. During a 15-day period, a total of 337 people completed the registration form and survey.

In Phase 2 (first week of September 2020), we organized a virtual session via Google Meet on solid waste management with the attendance of 120 people. The following day, we carried out a second session on waste segregation and explained to the participants the specific details of the study. After the second session, and before starting the data gathering phase, participants were given two days to install four segregations bins (Fig. 2) in their houses and replicate the training among the family members living with them (5.7 on average, this figure was calculated by making a simple average of the number of family members in each house). The selection of the four containers for waste separation corresponds to the Peruvian regulations (NTP 900.058:2019. Waste Management. Solid Waste Storage Colour Code).

Data collection was carried out using two Google Forms and a Word template. The Word template was used as a daily $\log$ for data recording; complementary to this, participants completed a Google form on day four (with data from day one to day four, Table S2) and a second Google form on day seven (with data from day five to day seven, Table S3). This double registration (on Word and Google forms) helps monitor and corroborate the data collected; Google forms facilitate the processing of the information in Excel spread sheets and the Word template is an easy way for collecting photographs.

In the Word template participants recorded their personal data, daily weighing measurements (Figure S2) and photographs taken. We request photographs of: the implementation of containers, organic waste, recyclable waste, non-recyclable waste, hazardous waste, recycling or repurpose of household waste (composting, eco-bricks, among others) and training of family members.

The waste was separated into six groups (Figure S2): (i) organic, (ii) recyclable, (iii) non-recyclable, (iv) hazardous, (v) eco-brick and (vi) used oil. Eco-bricks are plastic bottles packed with clean and dry, non-recyclable and nonhazardous waste used for building purposes. Used oil 
Table 1 Type of waste

\begin{tabular}{|c|c|}
\hline Type & Description \\
\hline Organic & $\begin{array}{l}\text { Peels and remains of fruits and vegetables; weed and pruning residues such as flowers, } \\
\text { leaves, stems, grass and other similar organic waste }\end{array}$ \\
\hline \multirow[t]{3}{*}{ Recyclable } & Terephthalate polystyrene \\
\hline & High-density polyethylene and polypropylene \\
\hline & Glass, metal, paper, cardboard and tetra pack \\
\hline \multirow[t]{3}{*}{ Non recyclable } & Sanitary waste: diapers and waste generated in the bathroom \\
\hline & Food waste \\
\hline & Others: fabrics, dust, expanded polystyrene, used paper towels, etc. \\
\hline Hazardous & Batteries, medicine waste, light bulbs, gloves, masks, etc. \\
\hline Eco-brick & $\begin{array}{l}\text { Candy and food wrappers, aluminium foil, medicine blisters, receipts paper, drinking } \\
\text { straws, etc. }\end{array}$ \\
\hline Used oil & Left over oil after food preparation \\
\hline
\end{tabular}

refers to oil and grease originated from the residential cooking process. The first four categories correlate to the segregated containers that were installed before starting the study (Fig. 2). The waste from these containers was weighed daily, reporting the partial sums on day four and day seven. In the case of the last two categories (eco-brick and used oil) only one weighing was carried out on day seven, since it is expected to generate fewer of these two types of waste. Table 1 details the type of waste for each of the six groups.

Table 1 details the type of waste for each of the six groups.

Given that the coronavirus could stay viable on the surface objects ranging from a few hours up to nine days (Kampf et al. 2020) there is a high possibility that masks and gloves can be contaminated with the coronavirus making them infectious waste (Manupati et al. 2021, Valizadeh et al. 2021), therefore they were classified as hazardous waste.

Recyclable wastes were weighed according to specific waste categories (terephthalate polystyrene; high-density polyethylene and polypropylene and; glass, metal, paper, cardboard and tetra pack). This classification responds to the interest of the Municipality of Comas to know the amount of plastic waste that would be generated as this type of waste has a higher sale value in the local recycling market. In order to have a greater detail of the composition of the non-recyclable waste, these were weighed following three categories (Table 1), the unclassifiable waste was placed in the "other waste" sub-category. Participants were instructed to store the used oil in plastic bottles for proper disposal instead of pouring it down the drain.

For Phase 3 of the study, data collection began after the container bins were installed at home and the participants trained their families. The seven-day study followed these sequence:

- Day 0: Elimination of all waste generated at home at the end of the day, so that day one begins without any waste at home.
- Day 1 to day 7: Daily weighing of the waste generated in each container, recording of the weights in the Word template (Figure S2).

- Day 4: Recording of the partial sum from day one to four in the Google form (Table S2).

- Day 4: Third training session in composting and organic gardens at home. This session also addressed any doubts the participants might have regarding the study.

- Day 7: Recording of the data from day five to seven on the Google form (Table S3), including data on the weight of the eco-brick and oil for the entire week. In this Google form participants also registered number of masks and gloves that were discarded as waste during the study week, and attached the Word template file.

Each participant carried out the weighing of the waste with different types of scales (top loading scales, mechanical weighing scales, digital receiving scales, digital price computing scales, hanging scales, etc.). The participants used the scales they had in their homes. In cases where they did not have scales, they were recommended to purchase a digital receiving scale (up to $10 \mathrm{~kg}$ ). As in a conventional waste characterization study, all waste was weighed wet.

A WhatsApp group was created to facilitate constant communication with the participants and to absolve any doubts they might have during the seven days of the study. We received between five to eight questions per day. Our team answered most of the questions within $2 \mathrm{~h}$. One week after the end of the characterization study (and after completion of Phase 3, the data analysis), a fourth and final session was organized. In this session we share with the participants the preliminary results of the study as well as the results of similar studies carried out in other locations.

In order to reduce the variability of the individual inputs a series of measures were applied: (i) training, (ii) constant monitoring and (iii) reviewing of pictures provided by the participants. In the second session held the participants were given specific details and instruction on how to conduct a 
waste characterization study, a series of examples were shown on how to segregate waste and what typo of waste to consider on each container. The WhatsApp group created served as means for participants to daily raise their questions regarding waste classification and weighing. Finally, the Word template file provide by the participants on day seven contained photos from each container; the project team review all the reports and photos to make sure all waste was properly classified.

\section{Waste Generation per Capita}

A total of 34 participants finished the seven-day characterization study. The data obtained with homemade hydrostatic balances and from less than four days were discarded. This resulted in a valid sample of 26 households.

The guideline for waste characterization of the Ministry of the Environment in Peru (Ministerio del Ambiente, 2019) was used for data processing and determination of the waste generation per capita (WPC) and waste composition.

The error (E) of estimation of WPC was calculated using Eq. (1), the sample number $(n=26)$ and the standard deviation $(\sigma=0.22)$ of the WPC.

$$
n=\frac{Z_{1-\alpha / 2}^{2} N \sigma^{2}}{(N-1) E^{2}+Z_{1-\alpha / 2}^{2} \sigma^{2}}
$$

In Eq. (1) $Z_{1-\alpha / 2}$ is the confident coefficient (1.96 in this study), (1- $\alpha)$ the confidence level (95\% in this study) and $N$ the population size. The value of the standard deviation is taken under the assumption that the population is normally distributed, and considering $95 \%$ reliability.

To compare the household WPC of this study with data from previous years we use the information from two reports elaborated by the Comas municipality in 2014 and in 2019. The Solid Waste Management Plan, elaborated in 2014 (Municipalidad Distrital de Comas 2014), indicates the household WPC for 2014 and projections for 2015, 2016 and 2017. The Waste Characterization Study published in 2019 (Municipalidad Distrital de Comas 2019) specifies the household WPC for that year.

\section{Limitations of the Methodology}

As with any proposed methodology, especially one that is based on participatory processes such as citizen science, there are limitations and assumptions that need reporting. Since the basis of this methodology is predominantly presenting a sampling method to collect waste data at the household level, the researchers assume particular conditions of the households participating in the survey. It is assumed that anyone expressing an interest to participate in the study would have access to the Internet at home and access to WhatsApp on their mobile devices. The need for a stable Internet connection to partake in the study can limit the scope of the sample especially in the rural and poor communities of a developing country. If the sample taken only considers participants with access to the Internet, it is only possible to sample medium and high socio-economic levels especially in developing and less developed countries. Though this is not a fully representative sample of the entire population, the methodology and its corresponding data can be customized and would have interpretive value to address specific community needs. This is pragmatic as a methodology for waste management studies as this is predominantly done on a community scale with each municipality having its own unique challenges.

At the pre-screening interface with interested participants, the research team exercises the resources and time to fully engage participants with the assumption of their full commitment to completing the processes in the study. As this study follows the standard research ethical principles which means that all participants are consenting, voluntary adults not classified as a vulnerable group and is allowed to withdraw from the study without the fear of any negative implications. The ethical standards dictate that participants could voluntarily withdraw at any time. The level of work and commitment (requiring engagement for seven days) can be too time consuming for many participants causing them to withdraw. Likewise, the laboriousness of the study implies that only people who recognize the importance of waste management will be motivated to participate during the seven days of study. Though this limitation maybe unavoidable, the researchers tried to manage this from happening by maintaining constant communication with participants via WhatsApp. The purpose for maintaining the constant communication is to address any concerns the participants may have, to encourage them in keeping up with the process and re-enforce the importance of the study to overall issue of waste management in the country as a means of motivation. This level of engagement by the research team does not lead to bias in the results and as the data comes from the participant conducting the waste segregation activity over the seven days and does not prompt any behavioural changes for favourable results. Further work is needed to explore other incentive methods to encourage participants to commit to the sampling process.

An important element in the methodology proposed is the use of scales to weigh the waste separated. The research team recognized that all participants would use varying scale types for the weighing activity. The variability in the type of scales used by the participants (top loading scales, digital receiving scales, hanging scales, mechanical scales, etc.) and the different weighing methods can contribute to the error in the WPC estimation. However, it might be the case that this error is counterbalancing and calibration and 
this does not take away from determining the composition of the residues with the quartering technique. To encourage the proper use of scales in weighing by participants, the communication engagement between the research team and participants was used to alleviate this challenge as the research team attempted to guide the participants in correctly conducting the weighing activities as outlined in Phase 3 of the methodology.

\section{Results and Discussion}

The household WPC is $0.421 \mathrm{~kg} / \mathrm{cap} *$ day with a standard deviation of 0.22 . Figure 3 depicts the household WPC from 2014, 2015, 2016, 2017, 2019 (Municipalidad Distrital de Comas 2014, 2019) and 2020. The bars in the WPC values indicate the error, $10 \%$ in the Waste characterization studies (Minam 2018) and 20.3\% in this study. The results suggest that in 2020 there was an apparent decline in the household WPC that can be attributed to the Covid-19 pandemic. This study shows a slight decrease in the WPC at the household level for 2020 that can attribute to a change in waste composition. With the quarantine measure of the pandemic, household consumption of consumer goods and services has decreased and the consumption of medical personal protective equipment (PPE) has increased. The change in waste composition weight can be attributed to the change in the volume distribution of consumer items at the household level. Zand and Heir (2021) demonstrated the change in composition of waste towards more medical PPE which affected the WPC in Iran.

Figure 4 shows the total metric tonnes of municipal waste (household waste plus commercial waste) collected monthly since 2015 in the Comas district. In the period

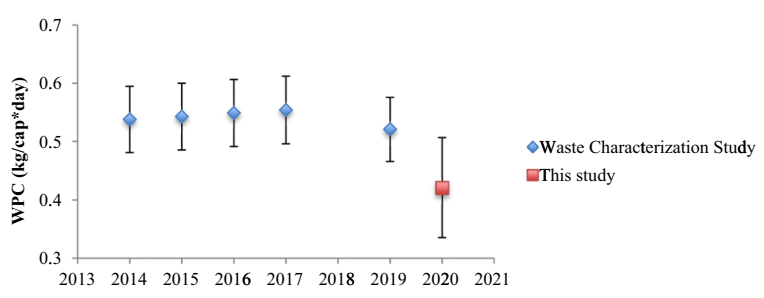

Fig. 3 Comparison of household WPC from 2014 to 2020

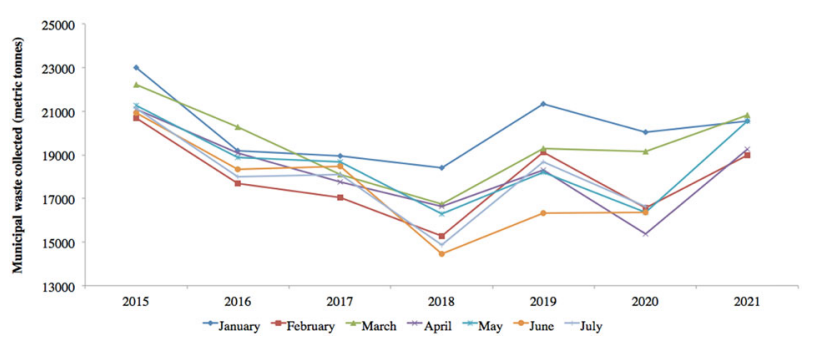

Fig. 4 Municipal solid waste collection in the Municipality of Comas
2015-2018 there is a decrease trend on waste collection. This reduction can be related to many things, one of them could be a mismatched between the amount formally reported and the amount actually collected. In 2019, with the entrance of a new mayor, the municipality made substantial efforts to increase waste collection; by mid 2018 the municipality acquire five new waste collection vehicles, this explains the increase from 2018 to 2019. Additionally, there is a clear decline in municipal waste collected between 2019 and 2020, and an increase between 2020 and 2021. The decrease between 2019 and 2020 is associated with the quarantine conditions in force since March, the reduction of commercial activities in the streets decrease the amount of waste collected. The increase between 2020 and 2021 is linked to the economic reactivation post quarantine.

Although there have been many reports for the increase of waste generation during quarantine (Pruett 2020, Sarkodie and Owusu 2020, Tenenbaum 2020), the decrease in solid waste during quarantine is a phenomenon that has been observed in other cities in Asia and Europe. In Milan there was a reduction of $27.5 \%$ in total waste; in Catalonia, a diminution of $16.65 \%$ of municipal waste and; in Barcelona, a $25 \%$ decrease in total waste (Sarkodie and Owusu 2020). In China, the government reported that the amount of municipal solid waste generated in large and medium-sized cities was reduced by $30 \%$ during the Covid-19 outbreak (Klemeš et al. 2020). Likewise, Fan et al. (2021) reported a $23 \%$ decline in municipal solid waste in Shanghai. In Latin America, the application of this methodology also evidenced a reduction in the generation of household waste in Lima (Peru) (Requena et al. 2020), Panama (Requena Sanchez et al. 2021a) and Honduras (Requena Sanchez et al. 2021b). This decrease may be due to a lower purchasing power of families caused by the economic recession resulting from the quarantine (Ikiz et al. 2021, Naughton 2020). It has been widely recognized that the shutdown of activities has caused large economic losses (Elsaid et al. 2021). Another explanation for the decrease in waste generation could be the sample selection as explained in the limitation of the methodology (Section Limitations of the methodology). The time-consuming aspect of the methodology implies that only motivated people participate; this group might have previously adopted practices to reduce the amounts of waste generated.

\section{Waste Composition}

Table 2 shows the composition of household waste obtained in the present study; $57.5 \%$ organic waste and $11.96 \%$ recyclable waste, more than half of recyclable waste was composed of plastic $(6.59 \%)$. Although the study population is of medium and middle-low income, their waste composition is similar to the typical composition of a lowincome population (Kaza et al. 2018); high percentage of organic waste and lower percentage of recyclable waste. 
Table 2 Household waste composition from this study

\begin{tabular}{llr}
\hline Group & Type & Percentage \\
\hline Organics & Fruit, vegetables and other & $36.46 \%$ \\
& green waste & \\
& Food waste & $21.04 \%$ \\
Recyclables & Polyethylene terephthalate & $3.71 \%$ \\
& High density polyethylene and & $2.88 \%$ \\
& polypropylene & \\
& Paper, cardboard, glass, metal, & $5.37 \%$ \\
Non recyclables & Setra pack & $18.17 \%$ \\
& Sanitary & $2.06 \%$ \\
& Hazardous & $1.82 \%$ \\
& Eco-brick & $1.50 \%$ \\
& Used oil & $6.99 \%$ \\
\hline
\end{tabular}

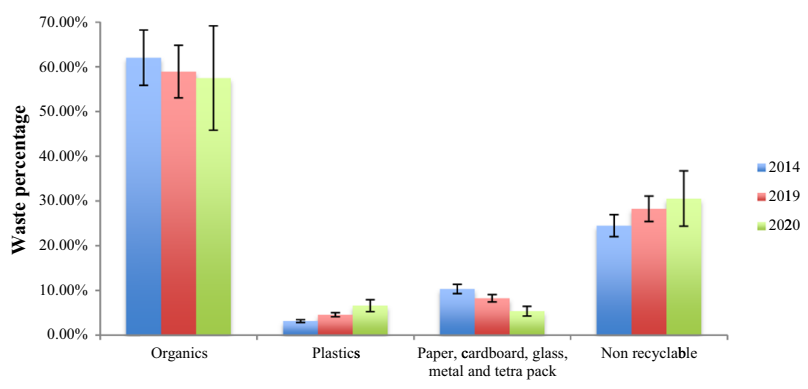

Fig. 5 Comparison of household waste composition

Nonetheless, the results obtained are similar to those of the municipal waste characterization study of Comas in 2019 (Municipalidad Distrital de Comas 2019) where the composition was found to be $58.9 \%$ organic waste and $10.84 \%$ recyclable waste.

Figure 5 depicts the household waste composition from 2014, 2019 (Municipalidad Distrital de Comas, 2014, 2019) and 2021. The bars in the percentage composition indicate the error, 10\% in the Waste characterization studies (Minam 2018) and $20.3 \%$ in this study. No major changes were detected in the proportion of organics; paper, cardboard, glass metal and; non-recyclable waste (Fig. 5). However, from 2019 to 2020 , an increase of $44.45 \%$ is observed on the composition of plastics (from 4.56 to $6.59 \%$ ).

The increase in plastics has been one of the many negative effects brought by that the pandemic (Patrício Silva et al. 2021). The main sources of plastic waste during the pandemic, in addition to PPE, are plastic food wrap, packaging plastics for pharmaceutical products and home delivery of food and supplies (Vanapalli et al. 2021) and, plastic containers from sanitizers (Benson et al. 2021). In Regina (Canada) Richter et al. (2021a) attribute the increase in residential waste disposal to increases in the use of single-use containers for takeout and food delivery services, and an increment in the use of PPE and disinfectant products. Increases in online food and grocery purchases have been reported in many cities in Asia and Europe; in Vietnam, India, China, Italy and Germany, online shopping increased between 12 and 57\% (Mu-Hyum 2020). Although online commerce also augmented in Latin America as a result of the pandemic (Forbes 2021), it is expected that this increase has been focused on the middle and high socioeconomic levels. In the study area, conformed by middle and lower middle class, part of the growth in the proportion of plastic waste may have been due to this reason. Another factor contributing to the surge of plastic waste has been modifications in consumer behaviour (Khoo 2021). The pandemic has changed, and reinforced, concerns for health and hygiene making most consumers to prefer products with plastic packaging and single-use plastic bags (Scaraboto et al. 2020, Tenenbaum 2020).

\section{Household Waste from the Covid-19 Pandemic}

In this study bio-contaminated waste like masks and gloves were considered as hazardous waste. As reported by the participants their hazardous waste consisted mainly of gloves and masks; and batteries, medicines and light bulbs to a lesser extent. According to the study results the daily per capita generation of masks and gloves is 0.124 and 0.085 . We estimate that each day $228 \mathrm{~kg}$ of disposable mask waste are being dispose in the district of Comas (Table 3). These waste, if bio-contaminated and not properly collected, transported and disposed, can result in sources of contamination (Mol Gomez and Caldas 2020, Wang et al. 2021). For example, at Soko Islands beach in Hong Kong, masks can be found every $100 \mathrm{~m}$ (Patrício Silva et al. 2021, Saadat et al. 2020). Given the proximity of the study area to the sea the possibility that a large number of masks and gloves end up in the ocean is high (the Comas district borders with the Chillón River to the north, between $23 \mathrm{~km}$ and $13 \mathrm{~km}$ before its mouth to the sea). Some alternatives or proper disposal methods include incineration, steam sterilization or microwave sterilization (Zhao et al. 2021).

Many authors have published articles with estimates of the daily generation of masks in different parts of the world (Table 4). Existing data are based on estimates, hypotheses, and arbitrary data; in all these cases, the estimate varies between 0.5 and 4 masks per person per day. Alternatively, the estimate based on quantitative data varies between 0.124 and 0.197 masks per person per day.

The data based on estimations assumes that the population uses surgical masks (Akber Abbasi et al. 2020, Benson et al. 2021, Sangkham 2020) and discards them after a single use (following the recommendations of the international health organizations (WHO 2020)). However, quantitative 
Table 3 Daily estimate of masks discarded in the study area

\begin{tabular}{llllll}
\hline & Population $^{1}$ & Use rate $^{2}$ & $\begin{array}{l}\text { Average daily masks per } \\
\text { capita }^{3}\end{array}$ & $\begin{array}{l}\text { Total daily } \\
\text { masks }\end{array}$ & $\begin{array}{l}\text { Total daily weight of } \\
\text { masks }^{5}\end{array}$ \\
\hline Comas 575,800 & $80 \%$ & 0.124 & 57,015 & $228 \mathrm{~kg}$ \\
\hline
\end{tabular}

1(CPI, 2019)/2People who leave their homes and need to wear masks (hypothetical data)/3This study/4 Total daily masks $=$ Population $\times$ Use rate $\times$ Average daily masks per capita/5 Considering that each mask weighs $4 \mathrm{~g}$ (Tripathi et al. 2020).

\begin{tabular}{|c|c|c|c|}
\hline Area & $\begin{array}{l}\text { Average daily masks } \\
\text { per capita }\end{array}$ & Acceptance rate & Reference \\
\hline \multicolumn{4}{|c|}{ BASED ON ESTIMATIONS } \\
\hline Africa & 2 & $80 \%$ & (Nzediegwu and Chang, 2020) \\
\hline Worldwide and Asia & 2 & $80 \%$ & $\begin{array}{l}\text { (Hantoko et al. 2021) according to } \\
\text { (Nzediegwu and Chang, 2020) }\end{array}$ \\
\hline Worldwide & 2 & $80 \%$ & $\begin{array}{l}\text { (Tripathi et al. 2020) according to } \\
\text { (Nzediegwu and Chang, 2020) }\end{array}$ \\
\hline Brazil & 2 & $80 \%$ & $\begin{array}{l}\text { (Urban and Nakada, 2021) according to } \\
\text { (Nzediegwu and Chang, 2020) }\end{array}$ \\
\hline Arabian Peninsula & 1 to 4 & $50 \%$ to $90 \%$ & (Akber Abbasi et al. 2020) \\
\hline Africa & 1 & $70 \%$ to $80 \%$ & (Benson et al. 2021) \\
\hline Asia & 1 & $80 \%$ & (Sangkham, 2020) \\
\hline Iran & 2 & $12 \%$ to $68 \%$ & (Zand and Heir, 2021b) \\
\hline Italy & 0.5 & - & (WWF, 2020) \\
\hline \multicolumn{4}{|c|}{ BASED ON QUANTITATIVE DATA } \\
\hline Comas, Lima, Peru & 0.124 & & This study \\
\hline Lima, Peru & 0.127 & & (Requena Sanchez and Carbonel Ramos, \\
\hline Arequipa, Peru & 0.134 & & 2020) \\
\hline Panama & 0.197 & & \\
\hline Honduras & 0.141 & & \\
\hline
\end{tabular}

Table 4 Comparison of estimated average daily masks per capita data suggests that people are not discarding used masks on a daily basis. This may be due to the reuse of surgical masks for economic reasons and the use of reusable cloth masks. Healthcare workers are more likely to use disposable surgical masks on a daily basis (Venesoja et al. 2021). Our data shows that non-healthcare workers are not using masks at the same rate.

Another aspect to take into account in the estimates of masks generated is the use of the "acceptance rate" that varies between 12 and $80 \%$, which is also based on arbitrary data. Although none of the reviewed articles (Table 4) explicitly defines the concept of "acceptance rate", it is understood in the Covid-19 literature on waste generation as the percentage of the population that actually uses masks. This "acceptance rate" is more adequate in countries where the use of masks is recommended but not compulsory; in places where the use of masks is mandatory it would be more appropriate to apply the "use rate" (Table 3). It is estimated that in more than 50 countries in America, Asia, Europe and Africa the use of masks is mandatory (Al Jazeera 2020). The "use rate" will depend on the percentage of the population that leaves their homes and have to wear a mask.
Based on all of the above we recommend that to estimate the quantity of masks generated it is important to consider the reuse of surgical masks, the use of reusable masks and the mandatory use of masks in the study area.

\section{Conclusions}

This study describes a participatory virtual methodology for household waste characterization in pandemic conditions using citizen science. The methodology consists of three phases (call and registration, training, and data collection and analysis) that are carried out with the help of virtual media such as social networks, Google Forms and Google Meet. The main limitations of the methodology lie in the variability of weighing, the need to have internet to participate in the study, awareness prior to the start of the study that could influence the generation of waste and, the laboriousness of the methodology that could reduce the level of participation. This methodology, in addition to being an instrument for collecting data on household waste generation and composition, it is also a citizen science tool 
for public awareness and training on household waste characterization and segregation. Its application reduces risk of contagion of Covid-19 and represents cost reduction and resource consumption due to the absence of fieldwork, when compare to a traditional waste characterization study.

This article presents the results of the application of the methodology in the district of Comas, located in Lima, capital of Peru. The participants weighed and separated their waste into four containers (organic, recyclable, nonrecyclable and hazardous), and two containers to elaborate an eco-brick and storage used cooking oil. The results suggest an apparent reduction in the household WPC in the area of study compared to 2019 . The latter could be due to the decrease in purchasing power caused by the economic recession during the quarantine. In comparison to the composition of waste from 2019 a slight increase is observed for plastics (from $4.56 \%$ in 2019 to $6.59 \%$ in 2020). In Comas, this could be attribute to consumers' concern for hygiene and health, which leads them to purchase products packaged in plastics and in single-use bags. Regarding masks and gloves, it is estimated that in the study area the daily generation of masks and pairs of gloves is 0.084 and 0.059 . There is a difference between the per capita generation of masks find in this study (and similar studies by the authors) from that estimated by other researchers. The results of this study suggest that people do not discard used masks on a daily basis, either for economic reasons or because they use reusable masks. This conduct should be taken into account for future estimations of the total amount of masks generated in any given city.

The use of citizen science in waste management research has immense potential for which this paper is only scratching the surface of possibilities. Covid-19 has forced environmental and social research to shift and find new methods to conduct research most having to incorporate the digital norms in society. The incorporation of the virtual environment and a participatory approach that engages the community to better understand their household waste dynamics presented in this paper is our novel contribution to enhancing the research capacity and data needs of many countries. More empirical work is needed on the varying applications and its applicability across different municipalities and countries. As outlined in the limitations, more research is needed on incentive mechanisms to ensure participants full engagement in the methodology and on possible adaptations to the methodology so that it can target low income and rural communities. Overall, the need for data on household waste especially in lieu of a global pandemic just demonstrates the complexity of effective waste management globally with developing and less developed countries unable to invest in comprehensive data collection frameworks. The uncertainties and vagaries in the waste management sector due to Covid-19 globally that is well documented in the literature has exposed the deficiencies in data to drive the necessary policies to sustainably manage the waste sector. The main lesson learnt by the waste management sector from this pandemic is that policy makers need to explore the options available in developing comprehensive waste management databases in order to effectively develop the necessary policies to manage future events like Covid-19.

\section{Data Availability}

The datasets generated during and/or analysed during the current study are available from the corresponding author on reasonable request.

Acknowledgements We would like to thank the voluntary work of the students from the Solid Waste Technical Team of the Faculty of Environmental Engineering of the National University of Engineering and the help of the officials from Office of Environmental Management of the Municipality of Comas.

Author Contributions Conceptualization, Methodology, Investigation: NR-S; Investigation: RK, LSP; Formal Analysis, Writing- Original draft preparation: DC-R; Writing- Reviewing and Editing: SM, KTWNg.

\section{Compliance with Ethical Standards}

Conflict of Interest The authors declare no competing interests.

Publisher's note Springer Nature remains neutral with regard to jurisdictional claims in published maps and institutional affiliations.

\section{References}

Adams B (2019) Commentary on Special Issue: Knowledge and Politics in Setting and Measuring $<\mathrm{scp}>\mathrm{SDG}</ \mathrm{scp}>$ s Numbers and Norms. Glob Policy 10(S1):157-158. https://doi.org/10. $1111 / 1758-5899.12639$

Adco P (2020) Estadísticas de redes sociales 2021 en Perú y Latinoamérica. Data.

Akber Abbasi S, Khalil AB, Arslan M (2020) Extensive use of face masks during COVID-19 pandemic: (micro-)plastic pollution and potential health concerns in the Arabian Peninsula. Saudi J Biol Sci 27(12):3181-3186. https://doi.org/10.1016/j.sjbs.2020.09.054

Al Jazeera (2020) Which countries have made wearing face masks compulsory? Al Jazeera News Agencie. https://www.aljazeera. com/news/2020/8/17/which-countries-have-made-wearing-facemasks-compulsory

Ambrose KK, Box C, Boxall J, Brooks A, Eriksen M, Fabres J, Fylakis G, Walker TR (2019) Spatial trends and drivers of marine debris accumulation on shorelines in South Eleuthera, The Bahamas using citizen science. Mar Pollut Bull 142:145-154. https://doi.org/10.1016/j.marpolbul.2019.03.036

Bashir MF, MA B, Shahzad L (2020) A brief review of socioeconomic and environmental impact of Covid-19. Air Qual, Atmosphere Health 13(12):1403-1409. https://doi.org/10.1007/ s11869-020-00894-8

Benson NU, Bassey DE, Palanisami T (2021) COVID pollution: impact of COVID-19 pandemic on global plastic waste footprint. Heliyon 7(2):e06343. https://doi.org/10.1016/j.heliyon.2021.e06343 
Burlea-Schiopoiu A, Ogarca RF, Barbu CM, Craciun L, Baloi IC, Mihai LS (2021) The impact of COVID-19 pandemic on food waste behaviour of young people. J Clean Prod 294:126333. https://doi.org/10.1016/j.jclepro.2021.126333

Carbery M, MacFarlane GR, O'Connor W, Afrose S, Taylor H, Palanisami T (2020) Baseline analysis of metal(loid)s on microplastics collected from the Australian shoreline using citizen science. Mar Pollut Bull 152:110914. https://doi.org/10.1016/j. marpolbul.2020.110914

Chen H, Wang S, Guo H, Lin H, Zhang Y (2020) A nationwide assessment of litter on China's beaches using citizen science data. Environ Pollut 258:113756. https://doi.org/10.1016/j.envpol.2019.113756

CPI (2019) Perú: Población 2019. http://cpi.pe/images/upload/pa ginaweb/archivo/26/mr_poblacional_peru_201905.pdf

Elsaid K, Olabi V, Sayed ET, Wilberforce T, Abdelkareem MA (2021) Effects of COVID-19 on the environment: An overview on air, water, wastewater, and solid waste. J Environ Manag 292:112694. https://doi.org/10.1016/j.jenvman.2021.112694

EMGIRS. (2020). Estadística de la operación del relleno sanitario de Quito y estaciones de transferencia. https://www.emgirs.gob.ec/ index.php/zentools/zentools-list

Fan YV, Jiang P, Hemzal M, Klemeš JJ (2021) An update of COVID19 influence on waste management. Sci Total Environ 754:142014. https://doi.org/10.1016/j.scitotenv.2020.142014

Forbes (2021) El eCommerce crece en América Latina con la pandemia. https://www.forbes.com.mx/america-latina-ecommerce-pa ndemia/

Fraisl D, Campbell J, See L, Wehn U, Wardlaw J, Gold M, Moorthy I, Arias R, Piera J, Oliver JL, Masó J, Penker M, Fritz S (2020) Mapping citizen science contributions to the UN sustainable development goals. Sustainability Sci 15(6):1735-1751. https:// doi.org/10.1007/s11625-020-00833-7

Hantoko D, Li X, Pariatamby A, Yoshikawa K, Horttanainen M, Yan M (2021) Challenges and practices on waste management and disposal during COVID-19 pandemic. J Environ Manag 286:112140

Ikiz E, Maclaren VW, Alfred E, Sivanesan S (2021) Impact of COVID-19 on household waste flows, diversion and reuse: The case of multiresidential buildings in Toronto, Canada. Resour, Conserv Recycling 164:105111. https://doi.org/10.1016/j.resconrec.2020.105111

INEI (2021) Planos estratificados de Lima Metropolitana a nivel de manzana 2020. https://www.inei.gob.pe/media/MenuRecursivo/ publicaciones_digitales/Est/Lib1744/libro.pdf

Islam, SMD-U, Mondal, PK, Ojong, N, Bodrud-Doza, M, Siddique, MAB, Hossain, M, \& Mamun, MA (2021). Water, sanitation, hygiene and waste disposal practices as COVID-19 response strategy: insights from Bangladesh. Environment, Development and Sustainability. https://doi.org/10.1007/s10668-020-01151-9

Jribi S, Ben Ismail H, Doggui D, Debbabi H (2020) COVID-19 virus outbreak lockdown: What impacts on household food wastage? Environ, Dev Sustainability 22(5):3939-3955. https://doi.org/10. 1007/s10668-020-00740-y

Kampf G, Todt D, Pfaender S, Steinmann E (2020) Persistence of coronaviruses on inanimate surfaces and their inactivation with biocidal agents. J Hospital Infect 104(3):246-251. https://doi.org/ 10.1016/j.jhin.2020.01.022

Kaza, S, Yao, L, Bhada-Tata, P, \& Van Woerden, F (2018). What a Waste 2.0: A Global Snapshot of Solid Waste Management to 2050. The World Bank. https://doi.org/10.1596/978-1-4648-1329-0

Khoo KS, Ho LY, Lim HR, Leong HY, Chew KW (2021) Plastic waste associated with the COVID-19 pandemic: Crisis or opportunity? J Hazard Mater 417:126108. https://doi.org/10. 1016/j.jhazmat.2021.126108

Klemeš JJ, Fan Y, Van, Tan RR, Jiang P (2020) Minimising the present and future plastic waste, energy and environmental footprints related to COVID-19. Renew Sustain Energy Rev 127:109883. https://doi.org/10.1016/j.rser.2020.109883
Manupati VK, Ramkumar M, Baba V, Agarwal A (2021) Selection of the best healthcare waste disposal techniques during and post COVID-19 pandemic era. J Clean Prod 281:125175. https://doi. org/10.1016/j.jclepro.2020.125175

Minam (2018) Guía para la caracterización de residuos sólidos municipales. https://sinia.minam.gob.pe/normas/aprueban-guiacaracterizacion-residuos-solidos-municipales

Ministerio de Salud (2021) Situación Actual COVID-19 Perú 20202021, 16 de junio

Ministerio del Ambiente (2019) Guía para elaborar la caracterización de Residuos Sólidos

Mitchell N, Triska M, Liberatore A, Ashcroft L, Weatherill R, Longnecker N (2017) Benefits and challenges of incorporating citizen science into university education. PLOS ONE 12(11): e0186285. https://doi.org/10.1371/journal.pone.0186285

Mol Gomez MP, Caldas S (2020) Can the human coronavirus epidemic also spread through solid waste? Waste Manag Res 38 (5):485-486. https://doi.org/10.1177/0734242X20918312

Moonsammy S, Oyedotun TDT, Renn-Moonsammy D-M, Oyedotun TD, Ally N, Kasim OF, Famewo A (2021) COVID-19 effects on municipality waste collection services for households: statistical modelling of perspectives from Guyana and Nigeria. Journal of Material Cycles and Waste Management. https://doi.org/10.1007/ s10163-021-01225-4

Mu-Hyum C (2020) Korea sees steep rise in online shopping during COVID-19 pandemic. ZDNet. https://www.zdnet.com/article/ korea-sees-steep-rise-in-online-shopping-during-covid-19-pa ndemic/

Municipalidad Distrital de Comas (2014) Plan de Manejo de Residuos Sólidos Municipales de Comas.

Municipalidad Distrital de Comas (2019) Estudio de caracterización de residuos sólidos municipales del distrito de Comas.

Municipalidad Distrital de Comas (2021) Geografía. Municipalidad Distrital de Comas. https://www.municomas.gob.pe/distrito/ geografia

Naughton CC (2020) Will the COVID-19 pandemic change waste generation and composition?: The need for more real-time waste management data and systems thinking. Resour, Conserv Recycling 162:105050. https://doi.org/10.1016/j.resconrec.2020.105050

Nghiem LD, Morgan B, Donner E, Short MD (2020) The COVID-19 pandemic: Considerations for the waste and wastewater services sector. Case Stud Chem Environ Eng 1:100006. https://doi.org/ 10.1016/j.cscee.2020.100006

Nowakowski P, Kuśnierz S, Sosna P, Mauer J, Maj D (2020) Disposal of Personal Protective Equipment during the COVID-19 Pandemic Is a Challenge for Waste Collection Companies and Society: A Case Study in Poland. Resources 9(10):116. https:// doi.org/10.3390/resources9100116

Nzediegwu C, Chang SX (2020) Improper solid waste management increases potential for COVID-19 spread in developing countries. Resour, Conserv Recycling, 161:104947. https://doi.org/10.1016/ j.resconrec.2020.104947

Ouhsine O, Ouigmane A, Layati E, Aba B, Isaifan R, Berkani M (2020) Impact of COVID-19 on the qualitative and quantitative aspect of household solid waste. Global Journal of Environmental Science and Management, 6(Special Issue (Covid-19)), 41-52. https://doi.org/10.22034/GJESM.2019.06.SI.05

Patrício Silva AL, Prata JC, Walker TR, Duarte AC, Ouyang W, Barcelò D, Rocha-Santos T (2021) Increased plastic pollution due to COVID-19 pandemic: Challenges and recommendations. Chem Eng J 405:126683. https://doi.org/10.1016/j.cej. 2020.126683

Pierini VI, Mazzeo N, Cazenave M, Semmartin M (2021) Waste generation and pro-environmental behaviors at household level: A citizen science study in Buenos Aires (Argentina). Resour, Conserv Recycling 170:105560. https://doi.org/10.1016/j.resconrec.2021.105560 
Pocock MJO, Roy HE, August T, Kuria A, Barasa F, Bett J, Githiru M, Kairo J, Kimani J, Kinuthia W, Kissui B, Madindou I, Mbogo K, Mirembe J, Mugo P, Muniale FM, Njoroge P, Njuguna EG, Olendo MI, Trevelyan R (2019) Developing the global potential of citizen science: Assessing opportunities that benefit people, society and the environment in East Africa. J Appl Ecol 56(2): 274-281. https://doi.org/10.1111/1365-2664.13279

Pruett M (2020) Coronavirus Consumer Trends: Consumer Electronics, Pet Supplies, and More. Criteo. https://www.criteo.com/ blog/coronavirus-consumer-trends/

Requena N, Medina S, Torres S, Diaz L (2020) El impacto del covid-19, en la composición de los residuos sólidos domiciliarios - estudio de caso en temporada de aislamiento social obligatorio. 1er Congreso Internacional Virtual de Manejo de Residuos Sólidos

Requena SN, Carbonel Ramos D (2020) Household waste characterization study in pandemic (Unpublished data)

Requena Sanchez N, Carbonel Ramos D, Erick V (2021) Generación y segregación de residuos sólidos domiciliarios durante la cuarentena por Covid-19 en Panamá, estudio de caso. Investigación y Pensam Crítico 9(2):16-24. https://doi.org/10.37387/ ipc.v9i2.232

Requena Sanchez, N, Carbonel Ramos, D, \& Romero Centeno, R (2021). Characterization of Honduras household waste during the Covid-19 pandemic (Manuscript submitted for publication).

Richter A, Ng KTW, Vu HL, Kabir G (2021a) Waste disposal characteristics and data variability in a mid-sized Canadian city during COVID-19. Waste Manag 122:49-54. https://doi.org/10.1016/j. wasman.2021.01.004

Richter A, Ng KTW, Vu HL, Kabir G (2021b) Identification of behaviour patterns in waste collection and disposal during the first wave of COVID-19 in Regina, Saskatchewan, Canada. J Environ Manag 290:112663. https://doi.org/10.1016/j.jenvman.2021.112663

Saadat S, Rawtani D, Hussain CM (2020) Environmental perspective of COVID-19. Sci Total Environ 728:138870. https://doi.org/10. 1016/j.scitotenv.2020.138870

Sangkham S (2020) Face mask and medical waste disposal during the novel COVID-19 pandemic in Asia. Case Stud Chem Environ Eng 2:100052. https://doi.org/10.1016/j.cscee.2020.100052

São Paolo (2020) Quantitativos: Resíduos coletados no município.

Sarkodie SA, Owusu PA (2020) Impact of COVID-19 pandemic on waste management. Environ, Dev Sustainability. https://doi.org/ 10.1007/s10668-020-00956-y

Scaraboto D, Jubert AM, Gonzales-Arcos C (2020) Using lots of plastic packaging during the coronavirus crisis? You're not alone. The Conversation. https://theconversation.com/using-lots-of-plastic-pa ckaging-during-the-coronavirus-crisis-youre-not-alone-135553

Sharma HB, Vanapalli KR, Cheela VS, Ranjan VP, Jaglan AK, Dubey B, Goel S, Bhattacharya J (2020) Challenges, opportunities, and innovations for effective solid waste management during and post COVID-19 pandemic. Resour, Conserv Recycling 162:105052. https://doi.org/10.1016/j.resconrec.2020.105052

Singh DK, Tirkey JV (2021) Valorization of Hazardous Medical Waste using Steam injected Plasma Gasifier: A Parametric Study on the Modeling and Multi-Objective Optimization by integrating Aspen Plus with RSM. Environmental Technology, 1-30. https:// doi.org/10.1080/09593330.2021.1946599

Tello Espinoza, P, Martínez Arce, E, Daza, D, Soulier Faure, M, \& Terraza, H (2011). Informe de la Evaluación Regional del Manejo de Residuos Sólidos Urbanos en América Latinay el Caribe 2010. https://publications.iadb.org/publications/spanish/document/ Informe-de-la-evaluación-regional-del-manejo-de-residuossólidos-urbanos-en-América-Latina-y-el-Caribe-2010.pdf
Tenenbaum L (2020) The Amount Of Plastic Waste Is Surging Because Of The Coronavirus Pandemic. Forbes. https://www. forbes.com/sites/lauratenenbaum/2020/04/25/plastic-wasteduring-the-time-of-covid-19/\#4e74328f7e48

Thakur V (2021) Framework for PESTEL dimensions of sustainable healthcare waste management: Learnings from COVID-19 outbreak. J Clean Prod 287:125562. https://doi.org/10.1016/j.jclepro. 2020.125562

Toledo Cervantes J, Díaz Núñez V, Martínez Rodríguez Ade (2020) Análisis de los hábitos en el manejo de los residuos Covid-19 en la vivienda y en los puntos limpios. Rev Científica de Arquitectura, Urbanismo Y Territorio 21:117-138. http://69.164.202. 149/topofilia/index.php/topofilia/article/view/103

Tripathi A, Tyagi VK, Vivekanand V, Bose P, Suthar S (2020) Challenges, opportunities and progress in solid waste management during COVID-19 pandemic. Case Stud Chem Environ Eng 2:100060. https://doi.org/10.1016/j.cscee.2020.100060

Urban RC, Nakada LYK (2021) COVID-19 pandemic: Solid waste and environmental impacts in Brazil. Sci Total Environ 755:142471. https://doi.org/10.1016/j.scitotenv.2020.142471

Valizadeh J, Hafezalkotob A, Seyed Alizadeh SM, Mozafari P (2021) Hazardous infectious waste collection and government aid distribution during COVID-19: A robust mathematical leaderfollower model approach. Sustain Cities Soc 69:102814. https:// doi.org/10.1016/j.scs.2021.102814

Vanapalli KR, Sharma HB, Ranjan VP, Samal B, Bhattacharya J, Dubey BK, Goel S (2021) Challenges and strategies for effective plastic waste management during and post COVID-19 pandemic. Sci Total Environ 750:141514. https://doi.org/10.1016/j.scitotenv. 2020.141514

Vega Córdova É (2021) Trabajo remoto: cuándo se podrá volver a las oficinas. Gestión. https://gestion.pe/economia/managementempleo/trabajo-remoto-cuando-se-podra-volver-a-las-oficinasteletrabajo-trabajo-a-distancia-mtpe-nnda-nnlt-noticia/

Venesoja A, Grönman K, Tella S, Hiltunen S, Koljonen K, Butylina S, Rotinen L, Torkki P, Laatikainen K (2021) Healthcare Workers' Experiences and Views of Using Surgical Masks and Respirators, and Their Attitudes on the Sustainability: A Semi-Structured Survey Study during COVID-19. Nurs Rep. 11(3):615-628. https://doi.org/10.3390/nursrep11030059

Vu HL, Ng KTW, Richter A, Karimi N, Kabir G (2021) Modeling of municipal waste disposal rates during COVID-19 using separated waste fraction models. Sci Total Environ 789:148024. https://doi. org/10.1016/j.scitotenv.2021.148024

Wang J, Chen Z, Lang X, Wang S, Yang L, Wu X, Zhou X, Chen Z (2021) Quantitative evaluation of infectious health care wastes from numbers of confirmed, suspected and out-patients during COVID-19 pandemic: A case study of Wuhan. Waste Manag 126:323-330. https://doi.org/10.1016/j.wasman.2021.03.026

WHO (2020) Coronavirus disease (COVID-19): Masks. https://www. who.int/news-room/q-a-detail/coronavirus-disease-covid-19-masks

WWF (2020) Nello smaltimento di mascherine e guanti serve responsabilità. WWF. https://www.wwf.it/scuole/?53500\%2FNello-sma ltimento-di-mascherine-e-guanti-serve-294

Zand AD, Heir AV (2021) Environmental impacts of new Coronavirus outbreak in Iran with an emphasis on waste management sector. J Mater Cycles Waste Manag 23(1):240-247. https://doi.org/10. 1007/s10163-020-01123-1

Zhao H, Liu H, Wei G, Wang H, Zhu Y, Zhang R, Yang Y (2021) Comparative life cycle assessment of emergency disposal scenarios for medical waste during the COVID-19 pandemic in China. Waste Manag 126:388-399. https://doi.org/10.1016/j.wasman.2021.03.034 